Vol. 14 (2005): 250-263.

\title{
Technical change in Finnish grass silage production
}

\author{
Timo Sipiläinen \\ MTT Agrifood Research Finland, Economic Research, Luutnantintie 13, FI-00410 Helsinki, Finland, \\ e-mail: timo.sipilainen@mtt.fi \\ Matti Ryhänen \\ Seinäjoki Polytechnic, School of Agriculture and Forestry, Ilmajoentie 525, FI-60800 Ilmajoki, Finland, \\ e-mail:matti.ryhanen@seamk.fi
}

\begin{abstract}
Stochastic production frontier analysis is applied in decomposing output growth of grass silage production to technical change, technical efficiency change, scale effect and input growth. For 1990-2000 in a complete panel of 138 Finnish farms, almost three fourths of the output growth was linked to input growth. The annual technical change, the shift of the production frontier, was on average 1.4 percent. Technical efficiency indicated a slightly decreasing tendency, less than 0.2 percent per year. Harvesting techniques were used as indicators of different technologies. The analysis showed that production frontiers differed between harvesting techniques. The choice of harvesting technique seemed to be related to circumstances on the farm. Thus, overall technical efficiency should not be interpreted as a measure of managerial competence when all the factors are not in the farmer's control. Controlling background and production environment related factors yields a considerably lower level of technical inefficiency than the models without the control. It is also shown that in general a more productive harvesting technique may be on average less efficiently utilized when compared to its own frontier.
\end{abstract}

Key words: productivity, technical efficiency, stochastic frontier

\section{Introduction}

In Finland a large share of livestock diets has consisted of grass - either pasture, hay or silage. The short growing season results in low yields and high costs of crop and forage production. Grazing is possible only for three-four months of the year and in the main dairy areas the pastures are either snow-covered or frozen half of the year. Thus, successful management of winter-feeding is an essential part of animal husbandry, both in economic and technical sense. In the central and northern parts of the country, milk and beef production based largely on grass silage has been the most viable form of agriculture. 
Vol. 14 (2005): 250-263.

While ruminants, especially dairy cows, require a relatively high share of forage in their diet, the proportion of silage, hay and cultivated grass pasture has amounted to almost one third of the total farmed land area in Finland. Forage for livestock has been typically produced on the same farm where it is consumed. The markets of silage have been irregular and local. Therefore, it has been practically impossible to build a livestock production system largely dependent on purchased grass silage. Because of limited supply of side products of the food processing industry, most farmers have to rely on silage produced on their own farms.

Since 1990 the area under silage production on livestock farms has substantially increased. Grass silage substituted for hay and especially after 1993, when milk quota became tradable and since 1995 when Finland joined European Union, milk production on specialised dairy farms started to grow. As simultaneously growing silage areas at the farm level indicate, a large share of diet still consists of grass silage although the fall in cereal prices at the time of EU-accession no more favoured grass silage based feeding as before.

Because the price level and price relations of purchased inputs are determined outside the farm, a possible decrease in unit costs of silage on the farm level has largely to be based on the increase in productivity. Productivity growth can be observed as an improvement of input output relationship. Two important sources of productivity growth have been widely recognized: technical change (an improvement in productivity due to a shift of the production frontier) and technical efficiency change (a catch up of the frontier) (e.g. Oskam and Stefanou 1997). The adoption of new technology is often related to a simultaneous change in the size of operation (Ryhänen 1994). The harvesting technique of grass silage has also improved rapidly. Many farmers have replaced their flail chopper based harvesting technique by precision chopping and round baling. These changes in harvesting techniques have also raised questions about their relative productivity and efficiency.

The analysis of productivity growth in milk production has typically been based on whole farm data (e.g. Bravo-Ureta and Rieger 1991, Ahmad and Bravo-Ureta 1995, Sipiläinen 2003). In this approach it is impossible to separate the contribution of various branches of production to the economic results of farms. However, the economic result of a livestock farm is largely dependent on how the farmer manages to arrange his/her feed supply. Therefore it is important to analyse the performance of feed production processes in more detail. This is likely to provide useful insights for successful management of livestock farms.

The aim of this paper is firstly to study the role of harvesting technique and of other background and production environment related factors in silage production. Comparisons are made whether these factors should be used as explanatory variables in the production function - simultaneously taking the possible heterogeneity into account - or as indicators explaining the differences in efficiency. Productivity and efficiency of different harvesting techniques are also studied. Secondly, the output growth in silage production is decomposed to productivity growth - technical change, technical efficiency change and scale effect - and input growth.

The paper is organised as follows. The principles of stochastic frontier analysis are presented in the next section. This is followed by the description of data set and estimated models. The fourth section contains empirical results and the last section concludes.

\section{Stochastic production frontier analysis in measuring productivity and efficiency}

Aigner et al. (1977) and Meeusen and van den Brock (1977) proposed simultaneously a parametric stochastic frontier production function with a composed error term including a stochastic error component and one-sided error component, which describes technical efficiency of produc- 
Sipiläinen, T. \& Ryhänen, M. Technical change in Finnish grass silage production

tion $^{1}$. When panel data is available stochastic frontier model can be specified to allow for the decomposition of productivity change into technical change, change in technical efficiency and scale effect. In addition, it is possible to investigate the role of input growth in output growth. Here, we apply the following translog specification (e.g. Battese and Coelli 1992):

$$
\begin{aligned}
\ln y_{i t}= & \beta_{0}+\sum_{j=1}^{h} \beta_{j} \ln x_{j i t}+\beta_{t} t+1 / 2 \sum_{j=1}^{h} \sum_{k=1}^{h} \beta_{j k} \ln x_{j i t} \ln x_{k i t} \\
& +1 / 2 \beta_{t t} t^{2}+\sum_{j=1}^{h} \beta_{j t} \ln x_{j i t} t-u_{i t}+v_{i t},
\end{aligned}
$$

where $y_{i t}$ refers to the output of $i^{\text {th }}$ firm in year $t, x_{j i t}$ $\left(x_{k i t}\right)$ is the input $j(k)$ used on the farm $i$ in year $t, t$ is the time trend, which captures exogenous technical change, $\beta$ 's are parameters to be estimated, $v_{\text {it }}$ is assumed as an independently and identically normally distributed error term, whose mean is zero and variance is constant and, $h$ is the number of inputs. $u_{i t}$ illustrates the deviation of each firm from the technically efficient frontier. This nonnegative inefficiency random variable is independently distributed of $\mathrm{v}_{\mathrm{it}}$.

The intuition behind this specification is that the deviation (technical (in)efficiency, $\mathrm{u}_{\mathrm{it}}$ ) from the frontier is a result of factors in the decision maker's control. The frontier itself can vary randomly across firms (random error term, $\mathrm{v}_{\mathrm{it}}$ ). The latter error component catches favourable and unfavourable uncontrollable events and possible measure-

1 Several methods can be applied in productivity and efficiency analysis. Often these methods are divided to non-parametric and parametric (e.g. Färe et al. 1994, Kumbhakar and Lovell 2000). An advantage of non-parametric programming models is that the analysis relies on only a few assumptions about production technology when in parametric econometric models a functional form has to be specified. On the other hand, in the empirical analysis the biggest problem of non-parametric models has probably been related to the deterministic nature of ordinary programming models. This is because extraordinarily deviating observations (outliers) may considerably affect the location of the frontier and, as a consequence the results of the efficiency and productivity analysis. ment errors. The problem is that one can only observe $\varepsilon_{\mathrm{it}}=\mathrm{v}_{\mathrm{it}}-\mathrm{u}_{\mathrm{it}}$, not the one-sided error term separately.

Battese and Coelli (1988) observed that a predictor for technical efficiency is defined as a conditional expected value

$$
\mathrm{TE}_{\mathrm{it}}=\mathrm{E}\left[\exp \left(-\mathrm{u}_{\mathrm{it}}\right) \mid \varepsilon_{\mathrm{it}}\right]
$$

Technical efficiency can be the same in each year for a specific firm or the level can change over time. Several specifications to capture this change have been presented. For example Battese and Coelli (1992) specified the change as follows:

$$
u_{i t}=u_{i} \eta(t)=\{\exp [-\eta(t-T)]\} u_{i}, \mathrm{t}=1, \ldots, T,
$$

where $\eta$ is a parameter to be estimated and $u_{i}$ follows a truncated normal distribution with a mean of $\mu$ and constant variance. Technical efficiency may increase, decrease or remain the same, but it changes similarly exponentially across firms. Cuesta (2000) has presented a stochastic frontier model, where this change can be firm specific $\left(\eta_{i}\right.$ instead of $\eta$ ). The latter model specification is complicated to estimate, and neither of previous models takes into account e.g. the heterogeneity in production circumstances as effects, which influence efficiency.

The factors influencing technical efficiency have in several studies been analysed by a second stage regression after the estimation of efficiency scores. There efficiency scores determined in the first stage regression have been regressed by background and production environment related factors (e.g. Pitt and Lee 1981). This, however, contradicts the assumptions of stochastic frontier analysis. In the estimation of efficiency scores of the stochastic frontier model it is assumed that the scores are independently and identically distributed but in the second stage regression the efficiency scores are assumed to depend on firm specific and other factors. This follows that efficiency scores cannot be identically distributed if the coefficients of dependent variables differ from zero (Coelli et al. 1998, 1999).

Kumbhakar et al. (1991) presented a model for cross-sectional data where environmental factors affect directly technical efficiency. In 1995, Bat- 
Vol. 14 (2005): 250-263.

tese and Coelli (1995) introduced a model for panel data, which made it possible to estimate parameter values for background or production environment related factors affecting technical efficiency simultaneously with separate components of technical efficiency and technical change. Efficiency is determined in a stochastic frontier model, where efficiency effects are assumed to distribute independently (but not identically) as non-negative random variables. For the period $t$ and firm i the technical inefficiency $u_{i t}$ in Equation 1 can be obtained from at zero truncated normal distribution $\mathrm{N}\left(\mu_{\mathrm{it}}, \sigma^{2}\right)$, where the mean $\mu_{\mathrm{it}}$ is defined as

$$
\mu_{\mathrm{it}}=\delta_{0}+\sum_{\mathrm{r}=1}^{\mathrm{m}} \delta_{\mathrm{r}} \mathrm{z}_{\mathrm{rit}}
$$

and $\mathrm{z}_{\mathrm{rit}}$ are the firm specific background or production environment related factors and $\delta_{\mathrm{r}}$ are parameters to be estimated. Thus, the means of at zero truncated normal distributions are not the same but functions of observed variables and a common parameter vector ${ }^{2}$. Efficiency scores of specific farms may vary from year to year. Technical change is expected to be caught by the ordinary production function.

It is not obvious whether the firm specific background and production environment related factors affect only directly technical efficiency. Alternatively, they can be included in the stochastic frontier model as direct effects on the shape and location of production frontier, in which case the equation can be written as follows

$$
\begin{aligned}
\ln y_{i t}= & \beta_{0}+\sum_{j=1}^{h} \beta_{j} \ln x_{j i t}+\beta_{t} t+1 / 2 \sum_{j=1}^{h} \sum_{k=1}^{h} \beta_{j k} \ln x_{j i t} \ln x_{k i t} \\
& +{ }^{1}{ }_{2} \beta_{t t} t^{2}+\sum_{j=1}^{h} \beta_{j t} \ln x_{j i t} t+\sum_{r=1}^{m} \theta_{r} z_{r i t}-u_{i t}+v_{i t},
\end{aligned}
$$

where $\mathrm{z}_{\mathrm{rit}}$ are the firm specific background or production environment related factors and $\theta_{\mathrm{r}}$ are their regression coefficients (Coelli et al. 1999). In Equation 5 above mentioned factors influence only

2 The model does not take into account possible correlation between periods and firms and random errors $\left(\mathrm{v}_{\mathrm{it}}\right)$, or the heteroscedasticity of random errors of technical efficiencies (Coelli et al. 1999). on the level of output. $\mathrm{u}_{\mathrm{it}}$ follows the truncated normal distribution where the mean $\mu_{\mathrm{it}}$ gets a constant value (of $\delta_{0}$ ). It is thus assumed that each firm faces a different frontier. This naturally influences the level of technical efficiency.

It is relatively straight forward to test whether some factors affect technical efficiency (Equation 4) or whether these factors influence the production frontier (Equation 5) applying nested tests. However, it is not possible directly to test whether background or production environment related factors are actually affecting the frontier or the distance from the frontier. This is tested applying the method suggested by Coelli et al. (1999), based on an artificial nested test. In this test, the same background or production environment related factors are used both as factors of production frontier and as factors explaining the variation of technical efficiency. This means that in Equation $5 \mathrm{u}_{\mathrm{it}}$ is the inefficiency term with a truncation at zero of $\mathrm{N}\left(\mu_{\mathrm{it}}, \sigma^{2}\right)$ and the mean $\mu_{\mathrm{it}}$ is defined as in Equation $4\left(\mu_{\mathrm{it}}=\delta_{0}+\sum_{\mathrm{r}=1}^{\mathrm{m}} \delta_{\mathrm{r}} \mathrm{z}_{\mathrm{rit}}\right)$. Thus, we can perform a nested likelihood ratio test by assuming either that $\theta_{r}$ or $\delta_{r}$ are jointly zero. In the latter case, $\mu_{i t}=\delta_{0}$, i.e. it is constant.

Total factor productivity (TFP) growth Divisia index is obtained as the difference between the output growth and input growth between the periods $\mathrm{t}+1$ and $\mathrm{t}$. Output growth (OG) is measured as a percentage change in output $O G=\left(\ln y_{i t+1}-\ln y_{i t}\right)$. The aggregate input growth (IG) is measured as $I G$ $=\sum_{j=1}^{h} 11_{2}\left(S_{i j t}+S_{i j t+1}\right)\left(\ln x_{i j t+1}-\ln x_{i j t}\right)$, where $\mathrm{S}_{\mathrm{ijt}}$ is the cost share of input $j$ at time $t$ on the farm i. By totally differentiating Equation 1 yields, in case of no allocative inefficiency, the following decomposition of TFP growth (Kumbhakar and Lovell 2000, p. 283-284)

$$
T F P=T C+S E+T E C .
$$

Thus, it can be decomposed to technical change (TC), scale effect (SE) and technical efficiency change (TEC). We next derive these components.

Technical change is obtained from the production function as the first derivative of $t$, which means that 
Sipiläinen, T. \& Ryhänen, M. Technical change in Finnish grass silage production

$$
T C=\frac{\partial \ln y_{i t}}{\partial t}=\beta_{t}+\beta_{t t} t+\sum_{j} \beta_{j t} \ln x_{j i t}
$$

where the two first elements of the equation determine neutral technical change and the last element input biased technical change. Technical change can be defined for each firm for each year applying the values linked to that firm. If technical change is unbiased it is equal for all farms.

Elasticity of output for input $\mathrm{j}$ at time $\mathrm{t}\left(\mathrm{E}_{\mathrm{ijt}}\right)$ can be calculated on the basis of coefficients of production function as follows:

$$
E_{i j t}=\frac{\partial \ln y_{i j}}{\partial \ln x_{i j}}=\beta_{j}+\beta_{j j} \ln x_{i j}+\sum_{\mathrm{k} \neq j} \beta_{j k} \ln x_{i k}+\beta_{j t} t
$$

Elasticities of scale can be determined as a sum of these elasticities $\left(\sum E_{i j t}\right)$. Thus, it may differ at each observation in a translog specification. In a Cobb-Douglas neutral technical change specification the elasticities are constant $\left(\beta_{j}\right)$ for all observations. The scale effect (SE) in productivity growth can be defined as

$$
\begin{gathered}
\mathrm{SE}=1 / 2\left(\left(\sum_{j=1}^{h} E_{i j t}-1\right)+\left(\sum_{j=1}^{h} E_{i j t+1}-1\right)\right) \sum_{j=1}^{h} 1 / 2\left(E_{i j t} /\right. \\
\left.\sum_{j=1}^{h} E_{i j t}+E_{i j t+1} / \sum_{j=1}^{h} E_{i j t+1}\right)\left(\ln x_{i j t+1}-\ln x_{i j t}\right)
\end{gathered}
$$

where $t$ and $t+1$ refer to sequential years. If elasticities of scale equals one the scale effect vanishes.

Technical efficiency change is a ratio of technical efficiencies in sequential years

$$
T E C=T E_{i t+1} / T E_{i t} .
$$

\section{Data and model}

The research data are collected from the Hila data base of the Finnish extension service, ProAgria Association of Rural Advisory Centres, for 1990 2000. In the data set it is possible to allocate the costs of crop production to each crop. This makes it also possible to analyse the changes in grass silage production separately. The sample farms are mainly specialised in milk production, and their silage production aims at meeting the forage requirements on the farms. We have excluded those farms, which have occasionally managed to get, in Finnish circumstances, exceptionally high yields (more than 10000 feed units per hectare) ${ }^{3}$. We concentrate our analysis on conventional farms and therefore the farms not applying any fertilisers are not included either ${ }^{4}$. Taking these constraints into account the number of panel farms reduces to 138 (1990-2000). The panel is complete. Most of the farms locate in the main milk production regions in Central Finland.

For estimation we have to choose between more inputs and the richness of technical details, which increases the risk of multicollinearity, and less inputs and higher level of aggregation, which may lead to a loss of useful information. In our production frontier analysis one output (the harvest of grass silage in feed units) and the following four inputs are considered: fertiliser, other variable input (including labour) capital (machinery and buildings) and land (harvested area of grass silage in hectares). Table 1 presents descriptive statistics of these variables on panel farms. There is a considerable variation both between farms and between years. The patterns of changes during the research period are not uniform either.

The inputs except land are originally measured as costs, and prices at the farm level are not recorded. In the production function analysis input quantities are required. If the farmers are assumed to face equal prices, we obtain implicit quantities by dividing each cost category by the respective input price index. We apply the input price indices

\footnotetext{
3 Feed unit is a quantity equivalent calculated on the basis of the energy value of one kilogram of barley. There are no farms that have obtained an average yield level close to or above $10000 \mathrm{fu} \mathrm{ha}^{-1}$. The observations are eliminated in order to diminish the effect of exceptional observations, like possible recording and assessing mistakes.

4 This is used as an indicator to exclude organic farms.
} 
Vol. 14 (2005): 250-263.

Table 1. Descriptive statistics of sample farms.

\begin{tabular}{lrr}
\hline & Mean & $\begin{array}{r}\text { Standard } \\
\text { deviation }\end{array}$ \\
\hline Output (feed unit) & 59335.53 & 24068.16 \\
Other variable (€) & 4840.15 & 1832.58 \\
Fertiliser (€) & 2323.13 & 858.35 \\
Capital (€) & 5564.10 & 2288.06 \\
Land area (ha) & 13.21 & 5.15 \\
\hline
\end{tabular}

published by Statistics Finland. However, the implicit quantities of labour input and the rest of other variable input have been calculated using the prices applied by ProAgria Association of Rural Advisory Centres. In our case the base year is 1998.

The harvested area of grass silage per farm has doubled from 1990 to 2000 . Output per hectare was high in 1990 and 2000. The lowest yields were received in 1991, 1998 and 1999. Output has increased by 6.6 percent per year on sample farms. This is mainly a result of an increase in input use and harvested area. Silage production per farms has increased every year. Output has increased of exceptional magnitude from 1999 to 2000 . When the harvested area has increased capital (machinery and building) input per hectare has decreased. At the same time the use of fertilisers per hectare has also diminished. Thus, the intensity of production has decreased.

In addition to above mentioned input and output variables, the data set includes indicators of harvesting techniques applied in silage production. The share of unwilted flail chopped silage has diminished while the share of precision chopping and round baling has increased during 1990s (Table 2). In the table the farms are classified by their main harvesting technique. The table shows that the observations on round baling have increased at
Table 3. Correlation matrix of logarithmic output and input variables.

\begin{tabular}{llllll}
\hline & \multicolumn{5}{c}{$\begin{array}{c}\text { Other } \\
\text { Output }\end{array}$} \\
& variable & Fertiliser & Capital & Land \\
\hline $\begin{array}{l}\text { Output } \\
\text { Other }\end{array}$ & 1 & & & & \\
variable & 0.825 & 1 & & & \\
Fertiliser & 0.744 & 0.815 & 1 & & \\
Capital & 0.732 & 0.655 & 0.640 & 1 & \\
Land & 0.836 & 0.963 & 0.813 & 0.666 & 1 \\
\hline
\end{tabular}

the end of 1990s and their share was still small in 2000. The indicators are used in determining technical efficiencies for different harvesting techniques.

The correlation matrix of logarithmic variables in Table 3 shows that in some cases the correlation between inputs is even higher than between the input and output. The correlation is especially high between the other variable input and land (the harvested area of grass silage), indicating that the use of other variable input increases almost by the same proportion as the acreage. Due to probable multicollinearity problems the fourth input, land is excluded from the following production frontier analysis ${ }^{5}$. The preliminary OLS analysis also showed that adding the fourth input could not significantly improve the fit of the model (the coefficients of determination were 0.866 and 0.872 respectively).

In our case we apply the computer program Frontier 4.1 (Coelli 1996). The program yields maximum likelihood estimates for the frontier pro-

5 Alternatively we could aggregate the two inputs. Because of uncertainties related to defining the price of land we preferred to exclude the input.

Table 2. Distribution of the main production techniques on sample farms.

\begin{tabular}{lrrrrrrrrrrr}
\hline & 1990 & 1991 & 1992 & 1993 & 1994 & 1995 & 1996 & 1997 & 1998 & 1999 & 2000 \\
\hline Flail chopping & 125 & 116 & 117 & 112 & 101 & 94 & 89 & 83 & 72 & 66 & 57 \\
Precision chopping & 13 & 21 & 20 & 22 & 34 & 43 & 47 & 52 & 54 & 52 & 56 \\
Round baling & 0 & 1 & 1 & 4 & 3 & 1 & 2 & 3 & 12 & 20 & 25 \\
\hline
\end{tabular}


Sipiläinen, T. \& Ryhänen, M. Technical change in Finnish grass silage production

duction function and technical efficiency measures for each farm ${ }^{6}$. It is assumed that technical efficiency and independent variables in the model do not correlate. The production technology was specified by a translog production frontier with non-neutral technical change as in Equation 1 where output $y_{i t}$ (harvest of grass silage yield in feed units) was determined as a function of fertiliser, other variable and capital inputs and their second order and cross terms with each other. Time trend $t$ is replaced by time dummies as an indicator of neutral technical change (Baltagi and Griffin 1988). $v_{i t}$ is the normal random error term and $u_{i t}$ represents technical inefficiency effects (a positive truncation of $\left.\mathrm{N}\left(\mu_{\mathrm{it}}, \sigma_{\mathrm{u}}^{2}\right)\right)$.

In addition, models take into account the effects of regions (four regions ${ }^{7}$, three dummy variables), production techniques (flail chopping, precision chopping and round baling, two dummies) and the share of grass silage area of the total arable land area of the farm ${ }^{8}$. Regional dummies can be expected to describe general differences of yield levels between regions, which are related to natural conditions. The natural conditions cannot be altered by the farmer but the farmer may adjust his/her operations to the prevailing conditions. The farmer is also able to choose the production technique and the share of arable land area under grass but these choices may also indicate the production conditions on the farm more generally. These factors may thus affect either the production frontier

6 The program uses a parameterization $\sigma^{2}=\sigma_{u}^{2}+\sigma_{v}^{2}$ and $\gamma=\sigma_{u} / \sigma$ where $\gamma$ lies between zero and one.

7 The regions are Uusimaa-Häme-Northern Savo, Central Ostrobothnia, Northern Karelia and Oulu.

${ }^{8}$ As possible explanatory variables the share of owned arable land area of the total area, the share of arable land area under grass silage, the logarithm of the arable land area and the share of arable land under subsurface drainage were investigated. Of those four before mentioned variables only the total arable land area was a significant dependent variable, but it correlated highly negatively with the share of arable land area under grass $(r=-0.49)$. The total arable land area was dropped from the model, and the share of arable land area under grass was used as an explanatory variable instead. or technical efficiency. Two alternative models to take into account the effects of regions, production techniques and the share of grass were specified. In the first set of models these variables are expected to affect directly the shape of the frontier like in Equation 5. In this case it is assumed that that each farm faces a different production frontier and technical efficiencies will be net of background and production environment related influences. In the second set of models the above mentioned variables affect directly technical efficiency as in Equation 4. In this case the farms share a common production frontier and background and production environment related factors influence only on the distance of each farm from the production frontier. These models are compared with the artificial test to a model where background and production environment related factors are affecting both the location of production frontier and technical efficiency.

It is obvious that the means of the farmer to adjust to the regional natural conditions (e.g. weather type) are limited. Separate models are specified for cases when the regional heterogeneity is controlled in the production frontier but the regional dummies are not used to explain technical inefficiency.

\section{Results}

Several alternative model specifications were estimated starting from the full translog model. According to the likelihood ratio ${ }^{9}$ (LR) test, the explanatory variables describing non-neutral technical change (cross terms of time trend and input quantity) could be excluded. This indicates that

$9 \mathrm{LR}=-2\left\{\ln \left[\mathrm{L}\left(\mathrm{H}_{0}\right)-\ln \mathrm{L}\left(\mathrm{H}_{1}\right)\right]\right\}$ where $\mathrm{L}\left(\mathrm{H}_{0}\right)$ ja $\mathrm{L}\left(\mathrm{H}_{1}\right)$ refer to the value of likelihood function under the null and alternative hypothesis, respectively. The test values are compared with the critical values of $\chi^{2}$-distribution with degrees of freedom equal to the number of restrictions (Coelli et al. 1998, p. 191). 
Vol. 14 (2005): 250-263.

technical change is not in this respect significantly biased on the sample farms. A large part of second order and cross terms of inputs is insignificant in the models considered, but the LR tests suggest that second order and cross terms of inputs cannot be dropped from the models. However, the correlation between first and second order terms is high resulting in unstable parameter estimates in the models. The instability refers to a multicollinearity problem in explanatory variables, and therefore the Cobb-Douglas functional form is preferred in the following more detailed analysis.

According to the LR test, both technical change and background or production environment related factors contribute significantly to the fit of frontier production function ${ }^{10}$. Therefore, they are included in all models. Technical (in)efficiency is significant in all models by the generalized likelihood ratio test of one-sided error as presented at the bottom of Table $4 \mathrm{a}$ and $4 \mathrm{~b}$.

Model 1 in Table $4 \mathrm{a}$ provides the frontier and the efficiency scores, which are related to the outer boundary of the production possibility set. Thus, it is related to efficiency of converting physical inputs into physical outputs. These gross efficiencies can then probably be decomposed into managerial and production environment related components (Coelli et al. 1999). In our case several of these components, e.g. the location of the farm, can be considered as fixed from the farmer's perspective. If this is the case the comparison between farmers is probably not fair. The same concerns the comparison between different harvesting techniques. If we cannot control possible differences in the circumstances the techniques are used we may end up with false conclusions about their relative performance.

The artificial nested test by Coelli et al. (1999) suggests that the model which includes background and production environment related factors

\footnotetext{
${ }^{10}$ For example in Model 2 the LR test values for the exclusion of background and production environment related factors is 427.14 and for further exclusion of neutral technical change it is 129.37 . These values are considerably larger than the critical values of 12.6 and 18.3 , respectively.
}

in the production function outperforms the model explaining technical efficiency effects. Models 1 to 3 in Table $4 \mathrm{a}$ represent the case when both the location of the farm, production technique and the share of grassland of total arable land area may affect either the production frontier directly or technical efficiency. The LR test indicates that the null hypothesis of no difference if the factors are eliminated from production frontier in Model 3 is rejected (Model 2) but in the case of eliminating technical efficiency effect factors from Model 3 it is maintained (Model 1, see Table 5). This suggests also that the choice of harvesting technique is more related to the circumstances on the farm than that the level of technical efficiency would be a result of the use of different harvesting techniques. When the background and production environment related factors are included in the production frontier the average efficiency (0.906) is considerably higher than when they are included only in the technical efficiency effect part (0.722).

The farmer cannot be expected to be able to control the regional effect on efficiency. Table $4 \mathrm{~b}$ presents the results of estimated models of 4 to 7 where regional heterogeneity of intercepts of frontier production functions is allowed but where no regional effects on technical efficiency exist. The likelihood ratio test between models 3 and 4 indicates that the regional dummies can be excluded from the model without a significant loss of the model fit: the critical value for eliminating the regional dummies from the technical efficiency effect model is 7.81 (at 5\% risk level) when the LR test value is 5.46. Models 2, 4 and 5 are used to test whether the production technique and the proportion of silage area of the total arable land area should be incorporated the production frontier or technical efficiency effect model. Also in this case the former is supported instead of the latter.

In Model 6 of Table 4b technology dummies affecting the slope parameters of production techniques are introduced. On the basis of likelihood ratio test, Model 2 without heterogeneous slopes is rejected in favour of Model 6 where these effects are included (Table 5). Therefore, it seems obvious that neglecting the above mentioned factors may cause bias in the estimation of frontier production 
Sipiläinen, T. \& Ryhänen, M. Technical change in Finnish grass silage production

Table 4a. Alternative model specifications.

\begin{tabular}{|c|c|c|c|c|c|c|c|}
\hline & Parameters ${ }^{1}$ & Model 1 & & Model 2 & & Model 3 & \\
\hline$\beta_{0}$ & constant & 1.4415 & $(9.05)$ & 1.3796 & $(9.76)$ & 1.3329 & $(9.71)$ \\
\hline$\beta_{\mathrm{M}}$ & $\ln \mathrm{M}^{2}$ & 0.5767 & $(22.31)$ & 0.5866 & (24.68) & 0.5871 & (23.94) \\
\hline$\beta_{\mathrm{F}}$ & $\ln F$ & 0.1581 & $(6.95)$ & 0.1450 & (7.11) & 0.1418 & $(6.73)$ \\
\hline$\beta_{\mathrm{K}}$ & $\ln K$ & 0.2324 & (12.81) & 0.2423 & (14.40) & 0.2405 & (14.39) \\
\hline$\beta_{\mathrm{D} 2}$ & time dummy & -0.0799 & $(-2.81)$ & -0.0972 & $(-3.58)$ & -0.0926 & $(-3.47)$ \\
\hline$\beta_{\mathrm{D} 3}$ & time dummy & -0.0553 & $(-1.89)$ & -0.0721 & $(-2.66)$ & -0.0682 & $(-2.54)$ \\
\hline$\beta_{\mathrm{D} 4}$ & time dummy & 0.0136 & (0.49) & 0.0001 & $(0.00)$ & 0.0011 & $(0.04)$ \\
\hline$\beta_{\mathrm{D} 5}$ & time dummy & -0.0519 & $(-1.78)$ & -0.0633 & $(-2.26)$ & -0.0591 & $(-2.15)$ \\
\hline$\beta_{\mathrm{D} 6}$ & time dummy & 0.0260 & $(0.90)$ & 0.0186 & (0.66) & 0.0219 & $(0.79)$ \\
\hline$\beta_{\mathrm{D} 7}$ & time dummy & 0.0731 & $(2.60)$ & 0.0580 & $(2.05)$ & 0.0557 & $(2.03)$ \\
\hline$\beta_{\mathrm{D} 8}$ & time dummy & 0.0841 & $(2.85)$ & 0.0798 & (2.79) & 0.0780 & $(2.78)$ \\
\hline$\beta_{\mathrm{D} 9}$ & time dummy & 0.0673 & $(2.34)$ & 0.0537 & (1.88) & 0.0555 & $(1.95)$ \\
\hline$\beta_{\mathrm{D} 10}$ & time dummy & 0.0763 & $(2.62)$ & 0.0627 & $(2.19)$ & 0.0666 & $(2.34)$ \\
\hline$\beta_{\text {D11 }}$ & time dummy & 0.1631 & $(5.33)$ & 0.1432 & $(4.81)$ & 0.1484 & $(4.95)$ \\
\hline$\theta_{1}$ & region(2) & & & 0.1815 & $(6.50)$ & 0.1891 & $(7.25)$ \\
\hline$\theta_{2}$ & region(3) & & & 0.1090 & $(3.70)$ & 0.1186 & $(3.53)$ \\
\hline$\theta_{3}$ & region(4) & & & 0.0724 & (2.93) & 0.1591 & $(6.84)$ \\
\hline$\theta_{4}$ & prec.chopping & & & 0.0900 & (6.13) & 0.1037 & $(8.21)$ \\
\hline$\theta_{5}$ & round baling & & & -0.0855 & $(-2.88)$ & -0.0850 & $(-2.12)$ \\
\hline$\theta_{6}$ & share of grass & & & -0.0049 & $(-16.17)$ & -0.0043 & $(-10.00)$ \\
\hline$\delta_{0}$ & constant & 0.0228 & $(0.27)$ & -7.2220 & $(-4.34)$ & -3.8519 & $(-11.95)$ \\
\hline$\delta_{1}$ & region(2) & -0.2219 & $(-5.13)$ & & & 0.0934 & (0.24) \\
\hline$\delta_{2}$ & region(3) & -0.1176 & $(-2.94)$ & & & 0.7393 & $(2.78)$ \\
\hline$\delta_{3}$ & region(4) & -0.0587 & $(-1.91)$ & & & 2.3380 & $(22.34)$ \\
\hline$\delta_{4}$ & prec.chopping & -0.1157 & $(-4.28)$ & & & 0.1108 & (2.49) \\
\hline$\delta_{5}$ & round baling & 0.0904 & $(2.72)$ & & & -0.0374 & $(-0.35)$ \\
\hline$\delta_{6}$ & share of grass & 0.0057 & (11.48) & & & 0.0066 & $(4.95)$ \\
\hline$\sigma^{2}$ & & 0.0584 & $(16.32)$ & 0.8113 & (4.80) & 0.2272 & $(7.20)$ \\
\hline$\gamma$ & & 0.4705 & (4.95) & 0.9519 & (90.39) & 0.8337 & (32.09) \\
\hline \multicolumn{2}{|c|}{ Log likelihood function } & 79.6820 & & 107.2310 & & 111.0200 & \\
\hline \multicolumn{2}{|c|}{$\begin{array}{l}\text { Likelihood ratio test of the } \\
\text { one-sided error }{ }^{3}\end{array}$} & 413.3700 & $(14.85)$ & 66.1720 & $(5.14)$ & 73.7500 & $(14.85)$ \\
\hline \multicolumn{2}{|c|}{ Technical efficiency } & 0.7220 & & 0.9060 & & 0.8940 & \\
\hline
\end{tabular}

${ }^{1} \mathrm{t}$-values in parenthesis

${ }^{2} \mathrm{M}$ is other variable input, $\mathrm{F}$ is fertiliser input and $\mathrm{K}$ is capital input.

${ }^{3}$ Critical values in parenthesis from Kodde and Palm (1986, p. 1246).

functions. Model 7 is similar to Model 6 but technical efficiency part allows for the efficiency effects of production techniques and of the share of grassland. Thus, the model shows whether the technical efficiency varies by production techniques when compared to their own frontiers.
The signs of estimated coefficients of background and production environment related variables are similar in all models with some exceptions. In the southern region output is lower than in other regions but the most productive farms are in Central Finland. The output level on precision 
Vol. 14 (2005): 250-263.

Table 4b. Alternative model specifications.

\begin{tabular}{|c|c|c|c|c|c|c|c|c|c|}
\hline & Parameters ${ }^{1}$ & Model 4 & & Model 5 & & Model 6 & & Model 7 & \\
\hline$\beta_{0}$ & constant & 1.3398 & $(9.68)$ & 1.2657 & (7.74) & 1.3242 & $(8.96)$ & 1.2729 & (7.68) \\
\hline$\beta_{\mathrm{M}}$ & $\ln \mathrm{M}^{2}$ & 0.5871 & (24.39) & 0.5829 & $(21.90)$ & 0.5361 & $(18.90)$ & 0.5387 & (18.43) \\
\hline$\beta_{\mathrm{F}}$ & $\ln F$ & 0.1451 & (6.98) & 0.1535 & (6.72) & 0.1648 & (6.54) & 0.1648 & $(6.60)$ \\
\hline$\beta_{\mathrm{K}}$ & $\ln K$ & 0.2426 & (14.55) & 0.2360 & (12.71) & 0.2766 & (13.65) & 0.2768 & (13.81) \\
\hline$\beta_{\mathrm{D} 2}$ & time dummy & -0.0982 & $(-3.67)$ & -0.0822 & $(-2.78)$ & -0.0917 & $(-3.40)$ & -0.0931 & $(-3.51)$ \\
\hline$\beta_{\mathrm{D} 3}$ & time dummy & -0.0721 & $(-2.70)$ & -0.0573 & $(-1.93)$ & -0.0660 & $(-2.48)$ & -0.0672 & $(-2.52)$ \\
\hline$\beta_{\mathrm{D} 4}$ & time dummy & -0.0035 & $(-0.13)$ & 0.0117 & $(0.39)$ & 0.0091 & $(0.33)$ & 0.0060 & $(0.22)$ \\
\hline$\beta_{\mathrm{D} 5}$ & time dummy & -0.0671 & $(-2.40)$ & -0.0541 & $(-1.80)$ & -0.0531 & $(-1.90)$ & -0.0588 & $(-2.17)$ \\
\hline$\beta_{\mathrm{D} 6}$ & time dummy & 0.0153 & $(0.56)$ & 0.0223 & $(0.74)$ & 0.0295 & (1.06) & 0.0263 & $(0.95)$ \\
\hline$\beta_{\mathrm{D} 7}$ & time dummy & 0.0550 & (1.99) & 0.0702 & $(2.36)$ & 0.0669 & $(2.38)$ & 0.0640 & $(2.30)$ \\
\hline$\beta_{\mathrm{D} 8}$ & time dummy & 0.0774 & $(2.74)$ & 0.0814 & $(2.69)$ & 0.0904 & $(3.17)$ & 0.0863 & $(3.05)$ \\
\hline$\beta_{\mathrm{D} 9}$ & time dummy & 0.0534 & $(1.87)$ & 0.0629 & $(2.08)$ & 0.0623 & (2.18) & 0.0604 & (2.13) \\
\hline$\beta_{\mathrm{D} 10}$ & time dummy & 0.0614 & $(2.12)$ & 0.0720 & $(2.35)$ & 0.0792 & $(2.73)$ & 0.0769 & $(2.67)$ \\
\hline$\beta_{\mathrm{D} 11}$ & time dummy & 0.1375 & $(4.58)$ & 0.1560 & $(4.87)$ & 0.1495 & $(5.01)$ & 0.1434 & (4.81) \\
\hline$\theta_{1}$ & region(2) & 0.1843 & $(6.68)$ & 0.1832 & $(6.24)$ & 0.1937 & $(6.97)$ & 0.1957 & (7.08) \\
\hline$\theta_{2}$ & region(3) & 0.1128 & $(3.86)$ & 0.1004 & $(3.25)$ & 0.1295 & $(4.37)$ & 0.1319 & $(4.46)$ \\
\hline$\theta_{3}$ & region(4) & 0.0743 & $(3.05)$ & 0.0719 & $(2.75)$ & 0.0845 & $(3.42)$ & 0.0859 & $(3.51)$ \\
\hline$\theta_{4}$ & prec.chopping & 0.1159 & $(5.41)$ & & & 0.1078 & (6.18) & 0.1322 & (7.11) \\
\hline$\theta_{5}$ & round baling & -0.0183 & $(-0.45)$ & & & -0.0975 & $(-2.57)$ & -0.0346 & $(-0.77)$ \\
\hline$\theta_{6}$ & share of grass & -0.0045 & $(-12.61)$ & & & -0.0048 & $(-15.68)$ & -0.0045 & $(-13.25)$ \\
\hline$\theta_{4 \mathrm{M}}$ & prec. ch.* $\ln M$ & & & & & 0.1439 & $(3.23)$ & 0.1438 & $(3.15)$ \\
\hline$\theta_{5 \mathrm{M}}$ & round $b . * \ln M$ & & & & & 0.0983 & $(1.23)$ & 0.1136 & (1.28) \\
\hline$\theta_{4 \mathrm{~F}}$ & prec. ch. $* \ln F$ & & & & & -0.0559 & $(-1.31)$ & -0.0567 & $(-1.32)$ \\
\hline$\theta_{5 \mathrm{~F}}$ & round b. ${ }^{*} \ln F$ & & & & & -0.0958 & $(-1.02)$ & -0.1140 & $(-1.11)$ \\
\hline$\theta_{4 \mathrm{~K}}$ & prec. ch. $* \ln K$ & & & & & -0.1256 & $(-3.65)$ & -0.1258 & $(-3.62)$ \\
\hline$\theta_{5 \mathrm{~K}}$ & round $b . * \ln K$ & & & & & 0.0363 & $(0.49)$ & 0.0231 & $(0.29)$ \\
\hline$\delta_{0}$ & constant & -6.0155 & $(-4.88)$ & -0.1075 & $(-1.44)$ & -7.0386 & $(-3.91)$ & -5.9565 & $(-3.80)$ \\
\hline$\delta_{4}$ & prec.chopping & 1.2221 & $(4.54)$ & -0.1230 & $(-4.37)$ & & & 1.2375 & $(3.54)$ \\
\hline$\delta_{5}$ & round baling & 2.0991 & $(5.46)$ & 0.0934 & (2.79) & & & 2.0409 & $(4.47)$ \\
\hline$\delta_{6}$ & share of grass & 0.0158 & $(5.40)$ & 0.0058 & (10.79) & & & 0.0136 & $(4.97)$ \\
\hline$\sigma^{2}$ & & 0.5443 & $(5.69)$ & 0.0576 & $(16.62)$ & 0.7727 & $(4.41)$ & 0.5383 & $(4.35)$ \\
\hline$\gamma$ & & 0.9297 & (64.66) & 0.4054 & $(3.47)$ & 0.9497 & (83.30) & 0.9285 & $(53.27)$ \\
\hline \multicolumn{2}{|c|}{ Log likelihood function } & 108.2920 & & 79.2050 & & 116.5720 & & 118.0100 & \\
\hline \multicolumn{2}{|c|}{$\begin{array}{l}\text { Likelihood ratio test of the } \\
\text { one-sided error }{ }^{3}\end{array}$} & 68.2930 & 10.37 & 342.9090 & 10.37 & 62.8180 & 5.14 & 65.6950 & 10.37 \\
\hline \multicolumn{2}{|c|}{ Technical efficiency } & 0.9000 & & 0.7440 & & 0.9080 & & 0.9030 & \\
\hline
\end{tabular}

${ }^{1} \mathrm{t}$-values in parenthesis

${ }^{2} \mathrm{M}$ is other variable input, $\mathrm{F}$ is fertiliser input and $\mathrm{K}$ is capital input.

${ }^{3}$ Critical values in parenthesis from Kodde and Palm (1986, p. 1246).

chopper farms is higher than on flail chopper farms, and on round baler farms it is the lowest. Increasing the share of grassland of the total arable land area tends to result in lower output. The direction of effects on technical efficiency has similar signs, i.e. a less productive farm is usually also 
Sipiläinen, T. \& Ryhänen, M. Technical change in Finnish grass silage production

Table 5. Hypothesis tests between models.

\begin{tabular}{lccc}
\hline & Likelihood ratio test & Degrees of freedom & Critical value at 95\% \\
\hline Model 1 vs. Model 3 & 62.77 & 6 & 12.6 \\
Model 2 vs. Model 3 & 7.58 & 6 & 12.6 \\
Model 4 vs. Model 3 & 5.46 & 3 & 7.81 \\
Model 5 vs. Model 4 & 58.17 & 3 & 7.81 \\
Model 2 vs. Model 6 & 16.56 & 6 & 12.6 \\
Model 6 vs. Model 7 & 2.88 & 3 & 7.81 \\
\hline
\end{tabular}

less technically efficient when background and production environment related factors are included only in the technical efficiency effect model.

The elasticities for specific inputs can be obtained from the first order coefficients of these inputs when we are estimating Cobb-Douglas type functions. It can be observed that the elasticities are the largest for other variable inputs $(>0.500)$ and the smallest for fertilizers $(<0.165)$. As Table $4 \mathrm{~b}$ shows, the first order coefficients of inputs in Model 6 and 7 differ by the harvesting technique. The elasticity of output in relation to other variable input (materials and labour) is significantly higher on precision chopper farms than on other farms. There is no significant difference between harvesting techniques in the output elasticity of fertilisers. On precision chopper farms the elasticity of capital (machinery and building) is significantly lower than on round baler and flail chopper farms. This is probably related to heavy investments necessary for this technique.
Elasticity of scale is close to one indicating that the silage output increases almost by the same proportion as inputs are increased. Elasticity of scale varies between 0.96 and 0.98 in different models. In Model 7, which allows for different elasticities in the three production techniques (as Model 6), indicates that elasticity of scale is the highest in the group of round baler farms (1.003) and the lowest on precision chopper farms (0.942). On the flail chopping farms elasticity of scale is close to one (0.980).

The pattern of technical change over the research period is similar in all estimated models. Annual variation is considerable and it is related to weather conditions. Table 6 shows the annual technical change, technical efficiency change and scale effect calculated on the basis of Model 7. The table also includes the growth rates of output and of cost share weighted aggregate input. These growth rates are also used to calculate the total factor productivity growth on the sample farms. The table

Table 6. Output growth, input growth and decomposition of total factor productivity growth (\%).

\begin{tabular}{lrrrrrrr}
\hline & $\begin{array}{c}\text { Output } \\
\text { growth }\end{array}$ & $\begin{array}{c}\text { Input } \\
\text { growth }\end{array}$ & $\begin{array}{c}\text { Total factor } \\
\text { productivity }\end{array}$ & $\begin{array}{c}\text { Technical } \\
\text { change }\end{array}$ & $\begin{array}{r}\text { Technical } \\
\text { efficiency } \\
\text { change }\end{array}$ & $\begin{array}{c}\text { Scale effect } \\
\text { Unexplained } \\
\text { residual }\end{array}$ \\
\hline $1990-91$ & 1.44 & 10.67 & -9.23 & -9.31 & -0.42 & 2.02 & -1.52 \\
$1991-92$ & 9.56 & 8.02 & 1.54 & 2.59 & 0.03 & -0.41 & -0.68 \\
$1992-93$ & 6.14 & -3.83 & 9.97 & 7.32 & -0.19 & 0.06 & 2.78 \\
$1993-94$ & 0.90 & 5.83 & -4.93 & -6.48 & -0.26 & -0.33 & 2.14 \\
$1994-95$ & 9.82 & 2.96 & 6.86 & 8.51 & -1.10 & 0.00 & -0.56 \\
$1995-96$ & 6.78 & -0.89 & 7.67 & 3.77 & 1.03 & 0.04 & 2.83 \\
$1996-97$ & 2.73 & 0.37 & 2.36 & 2.23 & -0.80 & 0.02 & 0.91 \\
$1997-98$ & 5.50 & 8.82 & -3.32 & -2.59 & -0.20 & -0.59 & 0.07 \\
$1998-99$ & 4.65 & 5.89 & -1.24 & 1.65 & -0.32 & -0.41 & -2.15 \\
$99-2000$ & 18.40 & 10.13 & 8.27 & 6.65 & 0.33 & -0.49 & 1.79 \\
Average & 6.59 & 4.80 & 1.79 & 1.43 & -0.19 & -0.01 & 0.56 \\
\hline
\end{tabular}


Vol. 14 (2005): 250-263.

also includes the unexplained residual component. The output has grown on average 6.6 percent per year when the input growth has been 4.8 percent. Thus, the annual TFP growth has been approximately 1.8 percent. The major factor contributing TFP growth is technical change (1.4 percent per year). Technical efficiency has been slightly decreasing $(-0.2$ percent per year) but the scale effect is on average close to zero. One third of the TFP growth remains unexplained in the residual.

Annual variation in the TFP growth is considerable. Time dummies approximate these changes relatively well. One interesting point in respect to annual changes is the effect of the EU accession. We can observe that the input growth was fastest in the beginning and at the end of the research period. At the time of the EU accession in the middle of the period it was at its lowest. Probably the uncertainties related to the rapid change in agricultural policy have postponed developing actions. In the TFP growth such a clear pattern cannot be observed since annual weather conditions have a major impact on output.

The way background and production environment related factors are incorporated in the model has an effect on the level of technical efficiency. Coelli et al. (1999) call these different efficiency scores as net efficiencies (when every farm is evaluated against its 'own' frontier taking background and production environment related factors into account) and as gross efficiencies (when the farms are evaluated against a 'common' frontier and the above mentioned factors are not included in the model). The average net efficiency obtained in Model 4 is 0.900 when the respective average gross efficiency in Model 5 is 0.744 . The difference is considerable but can be explained by the different procedure in taking the background and production environment related factors into account. Between Models 4 and 5 in Table 4b, the rank correlation of technical efficiencies is statistically significant (0.49). Thus, the ranking is not independent on the specification of the model although the correlation between different model specifications is high. The rank correlation of Models 2 and 4, respectively, in different model specifications is very high, 0.95 .
According to the non-parametric pairwise Wilcoxon score test, the average technical efficiencies differ significantly by production techniques at the probability of $99.9 \%$. In Model 5 when the heterogeneity related to production techniques is not controlled in the frontier production function, the average 'gross' technical efficiency is highest on precision chopper farms (0.824) and lowest on round baler farms (0.639). The average technical efficiency of flail chopper farms (0.719) lies between these two. Thus, the efficiency differences are considerable when the farms are compared to the common production frontier. Instead in the case of production technique specific frontiers of Model 7 the 'net' technical efficiencies were the highest on flail chopper farms (0.911), the second highest on precision chopper farms (0.892) and the lowest on round baler farms (0.859). This indicates that the technique may be less efficiently used compared to its 'own' frontier, although compared to the common frontier it is on average more efficient than other techniques.

\section{Discussion and conclusions}

This paper dealt with the determination of technical change, technical efficiency change and scale effect in grass silage production of 138 panel farms for 1990-2000. Additionally, the role of harvesting technique in technical change was analysed. An artificial nested test was introduced when the most appropriate model specification was searched for. The analysis was based on the stochastic frontier analysis (Battese and Coelli 1988, 1992, Coelli 1996).

According to the specified models, technical progress was approximately 1.4 percent per year. There seems not to be an obvious pattern in technical change but the annual variation is large. Estimated models show a slight tendency of falling technical efficiency but it is less than 0.2 percent per year. The silage area increased steadily during the research period resulting in a total output growth to exceed 6 percent per year. Although the 
input use per hectare dropped, the input growth at the farm level was the most important factor explaining the output growth. This result is in accordance to e.g. Ahmad and Bravo-Ureta (1995). The encouraging results of silage production are partially related to the typical phenomenon where the productivity of a developing branch of production increases more rapidly than the productivity of declining or stagnant branches. The productivity development of crop and forage production is probably not as positive at the whole farm level (Sipiläinen and Ryhänen 2002, Sipiläinen 2003).

There is a link between the shape of production frontier and harvesting technique, location of the farm and the share of arable land area under grass. The differences of production frontiers between harvesting techniques should probably be interpreted as an indicator of various production conditions and farmers' objectives than a primary source of efficiency or inefficiency. It has to be kept in mind what is the purpose of comparison: whether it is reasonable to compare all units to the best practise frontier or should one take into account background or production environment related differences - especially those, which the decisionmaker cannot affect. For example our analysis shows that in general precision chopping is the most technically efficient harvesting technique, but if we take into account the heterogeneity of production frontiers, precision chopper farms become actually less efficient relative to their own frontier than flail chopper farms. Round baler farms are less technically efficient than flail chopper farms independently of the model specification. We should, however, take into account that flail chopper farms have often avoided long term investments in their harvesting technique. It is also evident that harvesting with the flail chopper chain produces the highest field yields since in this technique the losses are the smallest at the time of harvesting. However, the losses are bigger in the storage and in feeding but this cannot be taken into account in the analysis when no records are available.

In the data set there was a tendency to replace flail chopping with precision chopping or round baling. There were also relatively few observa- tions on round baling, and these observations were concentrated at the end of the research period. More information is needed for firm conclusions about the relative performance of different harvesting techniques. More sophisticated analysis also sets high requirements for the data, especially if we should like to control different circumstances more comprehensively. Although the choice of harvesting technique may be a valuable indicator of the production conditions on the farm, it is only one part of the production chain which has to be considered when roughage production is organised.

Acknowledgements. We thank ProAgria Association of Rural Advisory Centres for providing us the data and Ministry of Agriculture and Forestry developing fond Makera for financial support.

\section{References}

Ahmad, M. \& Bravo-Ureta, B.E. 1995. An econometric decomposition of dairy output growth. American Journal of Agricultural Economics 1995(November): 314-921.

Aigner, D.J., Lovell, C.A.K. \& Schmidt, P. 1977. Formulation and estimation of stochastic frontier production function models. Journal of Econometrics 6:21-37.

Baltagi, B.H. \& Griffin, J.M. 1988. A general index of technical change. Journal of Policital Economy 96: 20-41.

Battese, G.E. \& Coelli, T.J. 1988. Prediction of firm-level technical efficiencies with a generalized frontier production function and panel data. Journal of Econometrics 38: 387-389.

Battese, G.E. \& Coelli, T.J. 1992. Frontier production functions, technical efficiency and panel data: with applications to paddy farmers in India. Journal of Productivity Analysis 3: 153-169.

Battese, G.E. \& Coelli, T.J. 1995. A model for technical inefficiency effects in a stochastic frontier production function for panel data. Empirical Economics 20: 325-332.

Bravo-Ureta, B.E. \& Rieger, L. 1991. Dairy farm efficiency measurement using stochastic frontiers and neoclassical duality. American Journal of Agricultural Economics 1991(May): 421-428.

Coelli, T.J. 1996. A guide to Frontier 4.1: a computer program for stochastic frontier and cost function estimation. Centre for Efficiency and Productivity Analysis. Working Paper 96/07. 33 p.

Coelli, T.J., Perelman, S. \& Romano, E. 1999. Accounting for environmental influences in stochastic frontier models: with applications to international airlines. Journal of Productivity Analysis 11: 251-273. 
Vol. 14 (2005): 250-263.

Coelli, T.J., Prasado Rao, D.S. \& Battese, G.E. 1998. An introduction on efficiency and productivity analysis. Kluwer Academic Publishers. Boston. 275 p.

Cuesta, R.A. 2000. A production model with firm-specific temporal variation in technical inefficiency: with application to Spanish dairy farms. Journal of Productivity Analysis 13: 139-158.

Färe, R., Grosskopf, S. \& Lovell, C.A.K. 1994. Production frontiers. Cambridge University Press. 296 p.

Kodde, D.A. \& Palm, F.C. 1986. Wald criteria for jointly testing equality and inequality restrictions. Econometrica 54(5): 1243-1248.

Kumbhakar, S.C., Ghosh, S. \& McGuckin, J.T. 1991. A generalized production frontier approach for estimating determinants of inefficiency in US dairy farms. Journal of Business and Economic Statistics 9(3): 279-286.

Kumbhakar, S.C. \& Lovell, C.A.K. 2000. Stochastic frontier analysis. Cambridge University Press. $331 \mathrm{p}$.

Meeusen, W. \& van den Broeck, J. 1977. Efficiency estimation for Cobb-Douglas production functions with composed error. International Economic Review 18: 435-444.
Oskam, A. \& Stefanou, S. 1997. The CAP and technological change. In: Ritson, C. \& Harvey, D. (eds.). The Common Agricultural Policy. Wallington UK. CAB International. p. 191-224.

Pitt, M.M. \& Lee, L.-F. 1981. Measurement and sources of technical inefficiency in the Indonesian weaving industry. Journal of Development Economics 9: 43-64.

Ryhänen, M. 1994. Input substitution and technological development on Finnish dairy farms for 1965-1991. Agricultural Science in Finland 3: 525-599.

Sipiläinen, T. 2003. Suurten tilojen suorituskyky ja sen kehittäminen. Summary: Performance of large dairy and cereal farms and its development. Helsingin yliopisto. Taloustieteen laitos. Julkaisuja nro 38.90 p.

Sipiläinen, T. \& Ryhänen, M. 2002. Tekninen tehokkuus ja tekninen muutos nurmisäilörehun tuotannossa. In: Ryhänen, M. \& Sipiläinen, T. (eds.). Nurmisäilörehu maitotilan taloudessa. Summary: Grass silage in the dairy farm economy. Helsingin yliopisto. Taloustieteen laitos. Julkaisuja nro 35. p. 57-99.

\title{
SELOSTUS
}

\section{Tekninen muutos suomalaisessa sällörehun tuotannossa}

\author{
Timo Sipiläinen ja Matti Ryhänen \\ MTT (Maa- ja elintarviketalouden tutkimuskeskus) ja Seinäjoen ammattikorkeakoulu
}

Tutkimuksessa sovellettiin stokastista tuotantorintamafunktioanalyysia, jonka avulla tuotoksen kasvu jaoteltiin tekniseen muutokseen, teknisen tehokkuuden muutokseen, skaalavaikutukseen ja panoskäytön kasvuun. Stokastinen tuotantorintama-analyysi eroaa tavanomaisesta tuotantofunktioanalyysista siten, että siinä virhetermi jaotellaan kahteen osaan: satunnaiseen vaihteluun ja etäisyyteen tuotantorintamasta. Tätä etäisyyttä kutsutaan tekniseksi tehottomuudeksi.

Tutkimuksessa käytettiin 138 suomalaisen tilan nurmisäilörehun tuotannon paneeliaineistoa vuosilta 19902000. Kyseisessä ProAgria Maaseutukeskusten liiton Hilaaineistossa lisääntynyt tuotantopanosten käyttö aiheutti noin kolme neljännestä reilun kuuden prosentin vuotuisesta tuotoksen kasvusta. Kokonaistuottavuuden kasvu oli 1,8 prosenttia vuodessa. Vuotuinen tekninen kehitys, tuotantorintaman siirtymä, oli noin 1,4 prosenttia. Tekninen kehitys vaihteli voimakkaasti vuodesta toiseen satovaihtelun myötä. Myös tekninen tehottomuus eli keskimääräinen etäisyys tuotantorintamasta kasvoi tutkimusajanjaksolla.

Tutkimusaineiston sisältämää tietoa tuotantomenetelmästä käytettiin luokittelevana tekijänä tehokkuus- vertailuissa. Analyysi osoitti, että tuotantorintamat eroavat toisistaan eri tuotantotekniikkoja käyttävillä tiloilla. Tuotantotekniikan valinta näyttää liittyvän tilan olosuhteisiin, sillä sisällyttämällä tuotanto-olosuhteita ja tekniikkaa kuvaavat tekijät tuotantorintamafunktioon saatiin parempi sovite kuin sisällyttämällä kyseiset tekijät teknistä tehokkuutta selittäviksi tekijöiksi. Siten myös tekninen tehokkuus on ainakin osittain kytköksissä tilan tuotanto-olosuhteisiin. Tuotantoympäristö- ja taustatekijöiden kontrollointi tuotantofunktiossa tuotti huomattavasti korkeamman tehokkuuden asteen kuin mallit, joissa näitä tekijöitä ei kontrolloitu. Yleisesti ottaen tuottavimmat, tarkkuussilppurikorjuuta harjoittavat tilat olivat keskimäärin tehottomampia kuin kelasilppurikorjuuta käyttäneet tilat, kun niitä verrattiin oman ryhmänsä tuotantorintamaan.

Tehokkuuden syiden yksityiskohtainen määrittäminen edellyttää jatkotutkimusta. Keskeistä olisi selvittää, millainen osuus tuotannon tehokkuudessa on liikkeenjohdolla ja erilaisilla tuotanto-olosuhde- sekä ympäristötekijöillä. 